\title{
Evaluation of a disposable stirred tank bioreactor for cultivation of mammalian cells
}

\author{
Alexander Hähnel', Benjamin Pütz ${ }^{3}$, Kai Iding ${ }^{2}$, Tabea Niediek², Frank Gudermann ${ }^{3}$, Dirk Lütkemeyer ${ }^{1,2^{*}}$ \\ From 22nd European Society for Animal Cell Technology (ESACT) Meeting on Cell Based Technologies \\ Vienna, Austria. 15-18 May 2011
}

\begin{abstract}
Introduction
Disposable bioreactors are increasingly gaining acceptance for cell culture applications due to a number of advantages including ease of use and reduced labour costs, less requirements for utilities such as steam and purified water. In addition, the system requires no cleaning or cleaning validation and only a reduced clean room footprint. Integrated ready to use pre-sterilised disposable sensors for $\mathrm{pH}$ and $\mathrm{dO}_{2}$ monitoring are expected to reduce the risk of contamination compared to conventional electrodes. Accordingly, a disposable pre-sterilised and therefore ready-to-use $200 \mathrm{~L}$ bioreactor featuring optical sensors for $\mathrm{dO}_{2}$ and $\mathrm{pH}$ has been evaluated for suspension culture of $\mathrm{CHO}$ cells in protein free media.
\end{abstract}

\section{Materials and methods}

Several fed-batch cultivations with a maximum cultivation time of 9 days were performed as follows.

Cells: Recombinant $\mathrm{CHO}$ cell lines producing monoclonal antibodies

Media: MAM-PF2, Bioconcept, Allschwil, Switzerland Feed and medium from Teutocell, Bielefeld, Germany Both media are chemically defined and protein free.

Feeds: Different commercial available amino acid concentrates, glucose and glutamine

Bioreactor: BIOSTAT ${ }^{\circledR}$ CultiBag STR 200 L, Sartorius Stedim biotech, Göttingen, Germany

Parameter control: Agitation of the culture was performed by a pre-installed magnetic driven stirrer with two 3-blade impellers at $80 \mathrm{rpm}, \mathrm{pH}$-adjustment via adding $\mathrm{CO}_{2}$ to the overlay stream and $\mathrm{dO}_{2}$ was

\footnotetext{
* Correspondence: dirk.luetkemeyer@fh-bielefeld.de

'Institute for Protein Characterisation, Faculty of Engineering and

Mathematics, University of Applied Sciences, Bielefeld, Germany

Full list of author information is available at the end of the article
}

controlled via aeration of pure oxygen through the ringsparger.

\section{Results}

Maximum cell densities between $5.0 \times 10^{6}$ and $1.3 \times 10^{7}$ cells $/ \mathrm{mL}$ with viabilities between $85 \%$ and $100 \%$ were achieved. Results of one typical fed-batch cultivation are shown in figure 1 .

The cell densities depended more on the medium performance and feeding strategy than on the bioreactorfeatures itself. At a cell density of $1.3 \times 10^{7}$ cells $/ \mathrm{mL}$ the volume flow of pure oxygen was at a rate of $0.85 \mathrm{~L} / \mathrm{min}$. In regard to the system's maximum flow rate of $20 \mathrm{~L} /$ min, the throughput of oxygen most likely would not become a bottleneck of even higher cell densities. Detailed comparison of the optical $\mathrm{pH}$ and $\mathrm{dO}_{2}$ probes with their conventional counterparts revealed a reliable concordant performance.

\section{Conclusion}

The disposable BIOSTAT ${ }^{\circledR}$ CultiBag STR 200 L bioreactor is a reliable cultivation system for high cell density operations above $10^{7}$ cells $/ \mathrm{mL}$ with mammalian cells. The usually installed ring-sparger supplies a sufficient amount of gas into the liquid phase and still offers adequate reserves. In direct comparison the optical sensors correlated excellently with the conventional electrodes. External pH-testing and recalibration is mandatory to compensate for the drift of the $\mathrm{pH}$-sensor. The reactor's overall performance is convincing in this field of operation, which is mainly due to its ease of use combined with the low utilisation of space. The set up procedure can be done in less than three hours which is remarkable compared with stainless steel bio-reactors and the advantage in prevention of cross-contaminants during changeover of campaigns is preeminent.

(c) 2011 Hähnel et al; licensee BioMed Central Ltd. This is an open access article distributed under the terms of the Creative Commons 


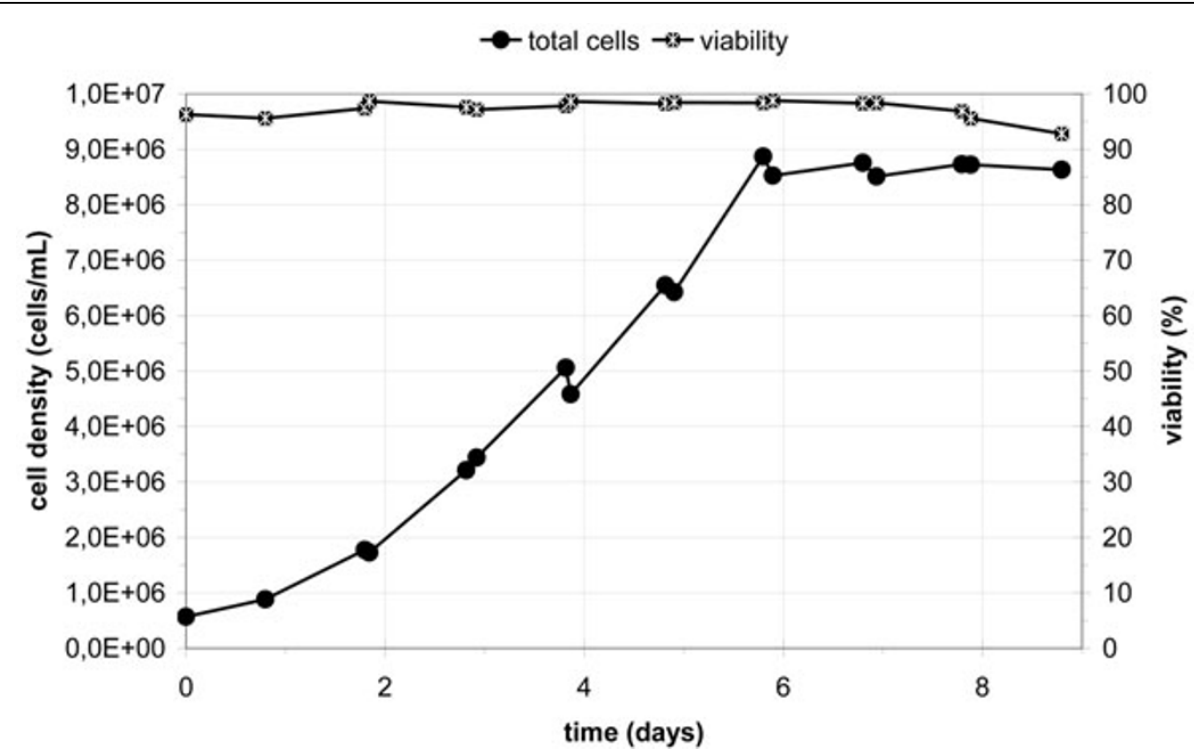

Figure 1 Cell growth and viability during a fed-batch cultivation of $\mathrm{CHO}$ cells in the $200 \mathrm{~L}$ disposable bioreactor.

\section{Acknowlegement}

The supply of materials by Dr. Greller and Mrs. Noack (Sartorius Stedim Biotech $\mathrm{GmbH}$ ) is greatly acknowledged.

\section{Author details}

'Institute for Protein Characterisation, Faculty of Engineering and

Mathematics, University of Applied Sciences, Bielefeld, Germany. ${ }^{2}$ BIBITEC

$\mathrm{GmbH}$, Bielefeld, Germany. Institute of Technical Analytics, Faculty of

Engineering and Mathematics, University of Applied Sciences, Bielefeld,

Germany.

Published: 22 November 2011

doi:10.1186/1753-6561-5-S8-P54

Cite this article as: Hähnel et al:: Evaluation of a disposable stirred tank

bioreactor for cultivation of mammalian cells. BMC Proceedings 20115

(Suppl 8):P54.

Submit your next manuscript to BioMed Central and take full advantage of:

- Convenient online submission

- Thorough peer review

- No space constraints or color figure charges

- Immediate publication on acceptance

- Inclusion in PubMed, CAS, Scopus and Google Scholar

- Research which is freely available for redistribution

Submit your manuscript at www.biomedcentral.com/submit 